\title{
Morphohistology and histopathology of the digestive organs of the deep-water fish greater forkbeard, Phycis blennoides
}

\author{
Zakia Alioua, Soumia Amira, Nesrine Semiane, Fatiha Zerouali-Khodja
}

Received - 21 December 2019/Accepted - 24 April 2020. Published online: 30 June 2020; @Inland Fisheries Institute in Olsztyn, Poland Citation: Alioua Z., Amira S., Semiane N., Zerouali-Khodja F. 2020 - Morphohistology and histopathology of the digestive organs of the deep-water fish greater forkbeard, Phycis blennoides - Fish. Aquat. Life 28: 99-112

\begin{abstract}
The aim of this paper was to report on an examination of the digestive organs in the deep-water fish Phycis blennoides (Brünnich) from Algerian coastal waters. A total of 1,019 specimens (5.7-62.7 cm in total length) obtained from commercial fisheries were examined between December 2013 and May 2017. The anatomical study was conducted using morphometric measurements of different sections of the digestive tract of $P$. blennoides. The histological features of the digestive tract were examined in the esophagus, stomach, intestine, and pyloric cecum. They were compatible with carnivorous feeding behavior and confirmed by a low intestinal quotient (IQ $=0.72 \pm 0.13$ ). The histopathological assessment highlighted the hepatic steatosis and parasitic infestation in its intestine from Anisakis simplex, which also occurs in Algerian coastal waters. According to our knowledge, this paper reports for the first time the morphohistological analysis of the digestive tract of a Phycidae species in Africa and provides the first histopathological assessment of the digestive organs of the greater forkbeard in the southwestern Mediterranean Sea.
\end{abstract}

Keywords: Phycis blennoides, digestive tract, hepatic steatosis, Anisakis simplex, Algeria

\footnotetext{
Z. Alioua [ $\left.\Xi^{\circ}\right]$, S. Amira, F.Zerouali-Khodja

Fisheries Laboratory, Faculty of Biological Sciences, University of Sciences and Technology Houari Boumediene Algiers, Algeria e-mail: zakia.alioua@gmail.com

N. Semiane

Nutrition Laboratory, Faculty of Biological Sciences, University of Sciences and Technology Houari Boumediene Algiers, Algeria
}

\section{Introduction}

Pollution and overexploitation are the main factors that might be responsible for fish stock depletion. Deep-water fishes are among various species that have been affected by these factors leading to reducing catches. They are currently vulnerable and are exhibiting toxicopathic changes (Feist et al. 2015) and other idiopathic lesions (Stentiford et al. 2009). This vulnerability is linked to their life history traits of slow growth, extreme longevity, old age maturation (Devine et al. 2006), and a high trophic level. Among these species, the greater forkbeard, Phycis blennoides (Brünnich) inhabits Algerian deep-sea waters. Commonly known as the Mistelle El-Beida in the local dialect, it is mainly caught with demersal trawls and longlines over a large portion of the continental slope (Matarrese et al. 1998). This species is generally found on sandy and muddy bottoms from only 10 meters (Cohen et al. 1990) along the coastline to depths of $1850 \mathrm{~m}$ (Rotllant et al. 2002). It is mainly carnivorous and is an important predator of the deeper shelf and upper slope communities. It feeds on various food items such as crustaceans and fishes in particular, in addition to cephalopods, Polychaeta, and plants (Alioua et al. 2018).

Among information available on $P$. blennoides in the Mediterranean, some authors are interested in its 
biology (Rotllant et al. 2002, Benghali et al. 2014) and bathymetric distribution, (Massutí et al. 1996) while others have estimated its age and growth parameters (Casas and Pińeiro 2000, Romdhani et al. 2016). There are also several other studies on its diet composition (Macpherson 1978, Morte et al. 2002, Sartor 1995), trophic level (Alioua et al. 2018), health status assessment (Marcotrigiano and Storelli 2003, Storelli et al. 2008, Solé et al. 2009), and parasitic community (Farjallah et al. 2006, Dallarés et al. 2016). However, the description of its digestive organs remains unknown with no publications on the digestive systems of any Phycidae. Knowledge of digestive tract differentiation is essential to understanding its nutritional physiology, which is correlated with its food and feeding habits (Alabssawy et al. 2019). According to Al-Abdulahadi (2005), the digestive systems of fishes are remarkable in their morphological and functional diversity. Gastrointestinal tracts vary greatly among fish species (Ray and Ringø 2014) and are related to taxonomy (Al-Abdulahadi 2005) and feeding habits (Geistdoerfer 1981). Since some morphological and functional differences occur in the digestive tracts of fishes depending on their diets, it is important to determine whether the digestive tract morphology of $P$. blennoides is consistent with its feeding habits. The lack of knowledge on the digestive system of $P$. blennoides in the Mediterranean, including its ecological status in Algeria, prompted us to conduct this study. Environmental changes can damage the anatomical and histological structures of this species. Consequently, our investigation aimed to provide data on the presence of pathological changes in the organs of P. blennoides, and it is the first report of a morphohistological analysis of the digestive tract of a Phycidae species in Africa.

\section{Material and Methods}

\section{Study area and sampling}

The Algerian basin in the western Mediterranean is situated off the southern Levantine coast of the
Iberian Peninsula, between the Balearic Islands to the west of Sardinia and the coast of Algeria (Moranta et al. 2008). It has maximum depths of around $2500 \mathrm{~m}$ and is connected with the Balearic basin by a series of sills (Moranta et al. 1998). The Algerian coast extends over $1,622 \mathrm{~km}$ of the southwestern Mediterranean coastline from the Moroccan to the Tunisian borders (Grimes et al. 2018).

A total of 1,019 specimens of $P$. blennoides obtained from Algerian commercial fisheries were studied between December 2013 and May 2017. They were collected at random from nine fishing ports (Mostaganem, Tenes, Cherchel, Bouharoun, Ain El-Benian, Algiers, Zemmouri, Azeffoun, and Annaba) on the Algerian coast (Fig. 1). Total length (TL: 5.7-62.7 cm in total length), total weight (TW: 1.27-1,969.3 g), and stomach weight $\left(\mathrm{W}_{\mathrm{st}}\right.$ : 0.01-48.53 g) were recorded for each individual. All livers were removed, weighed $\left(\mathrm{W}_{\mathrm{L}}: 0.01-116.05 \mathrm{~g}\right)$, and examined macroscopically. The weight variations of each parameter $\left(\mathrm{TW}, \mathrm{W}_{\mathrm{st}}, \mathrm{W}_{\mathrm{L}}\right)$ were examined, and the hepatosomatic index (HSI) was estimated with the following equation: $H S I=\frac{100 \times W_{L}}{T W}$.

\section{Morphological study}

Morphometric measurements of the different digestive tract sections were taken on 29 individuals of $P$. blennoides. The lengths of the esophagus $\left(\mathrm{L}_{\mathrm{oso}}\right)$, the stomach $\left(\mathrm{L}_{\mathrm{st}}\right)$, the intestine $\left(\mathrm{L}_{\mathrm{int}}\right)$, the rectum $\left(\mathrm{L}_{\text {rect }}\right)$, and the digestive tract $\left(\mathrm{L}_{\text {tract }}\right)$ were measured, and the number of pyloric ceca were counted ( $\left.\mathrm{N}_{\text {Ceacum }}\right)$. The ratio $(R)$ between the length of the digestive tract and fish weight was estimated, as follow: $R=\frac{L_{\text {tract }}}{T W}$

To indicate the diet of the species, the intestinal quotient (IQ) was calculated by the ratio of the intestine length and the body length as follows: $I Q=\frac{L_{\text {int }}}{T L}$; where IQ $<1$ indicates a carnivorous diet, $1<$ IQ $<3$ omnivorous diet, and IQ $>3$ herbivorous or detritivorous diets (Ward-Campbell et al. 2005). 


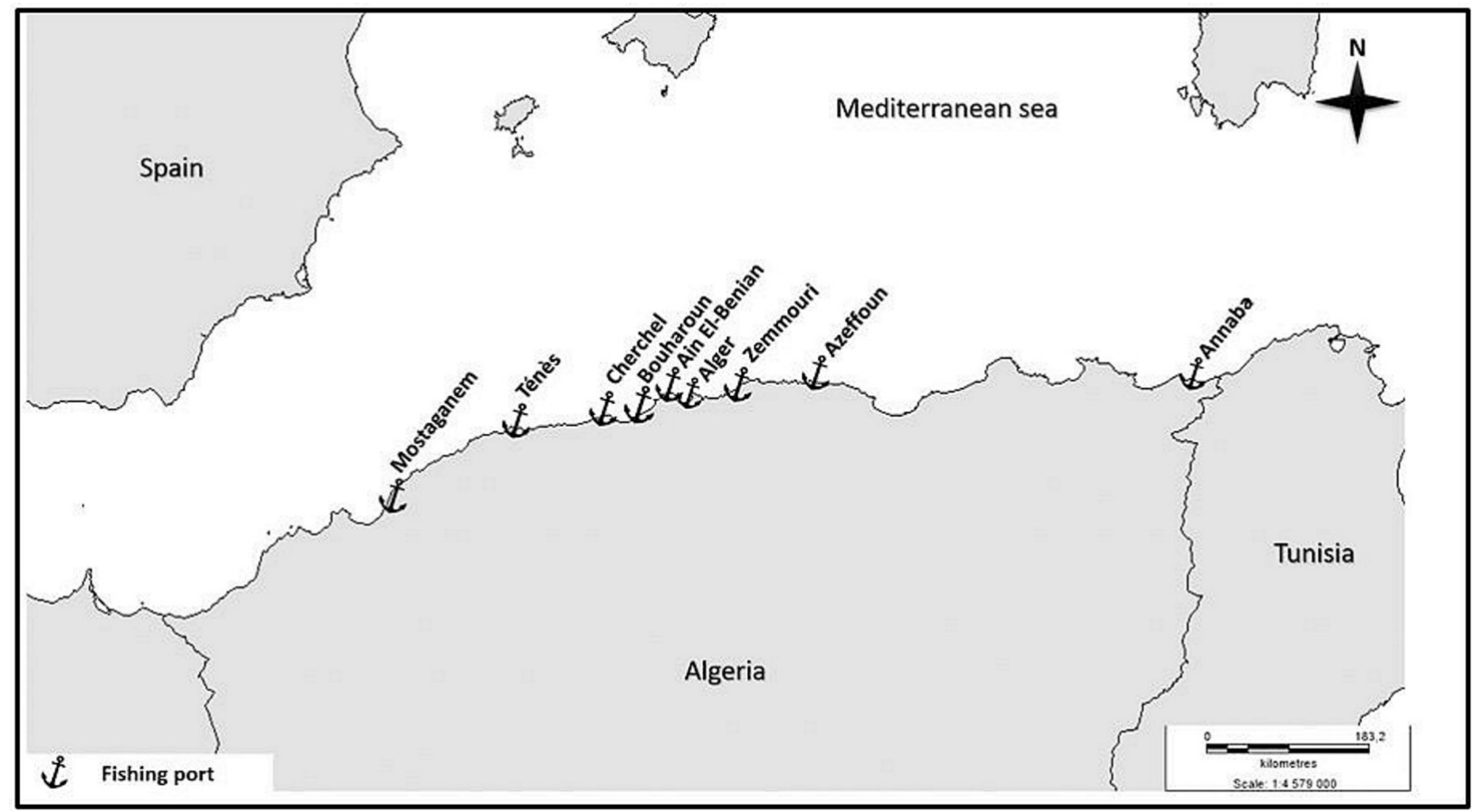

Figure 1. Study area of Phycis blennoides.

Variation in all the parameters (TW, $\mathrm{W}_{\mathrm{st}}, \mathrm{W}_{\mathrm{L}}$, HSI, $\mathrm{L}_{\mathrm{oso}}, \mathrm{L}_{\mathrm{st}}, \mathrm{L}_{\text {int }}, \mathrm{L}_{\text {rect }}, \mathrm{L}_{\text {tract }}, \mathrm{N}_{\text {Ceacum }}, \mathrm{R}$, and IQ) were studied in three fish size classes. These were chosen according to the length at first maturity estimated by Rotllant et al. (2002) of approximately 20 $\mathrm{cm}$. All specimens measuring less than $20 \mathrm{~cm}$ in total length were included in the juvenile class. Mature fish were divided into medium and large classes. The medium category included fish from 20 to $30 \mathrm{~cm}$, while the large class included specimens longer than $30 \mathrm{~cm}$.

\section{Histological study}

During macroscopic examinations of the shape, texture, and color of livers, four were selected for microscopic examination. Then, two livers with an abnormal color and two others with normal characteristics were prepared for histological analyses. Additionally, five digestive tracts and the spleen of an infested specimen were also prepared for histological analyses. The selected organs were fixed in a formaldehyde solution (10\%), dehydrated in alcohol solutions, and infiltrated with paraffin for $24 \mathrm{~h}$ in a Spin Tissue Processor STP 120 Myr. The tissues were embedded in paraffin and sectioned at 3-7 $\mu \mathrm{m}$ using a Leica RM2125 RT microtome. Slides were stained (hematoxylin-eosin: H\&E, Trichrome of Masson, Periodic Shiff Reactive Acid: PAS) and viewed under a Premiere T3.15A microscope. A Premiere Cam connected to a computer took micrographs using the TSView image analysis software (Version 6.2.4.5. Tucsen, China).

\section{Statistical analysis}

Relationships between fish length and liver weight $\left(\mathrm{TL} \sim \mathrm{W}_{\mathrm{L}}\right)$ and between fish length and stomach weight $\left(\mathrm{TL} \sim \mathrm{W}_{\mathrm{st}}\right)$ were determined using a linear regression model. Analysis of variance (ANOVA) was used to evaluate differences in the morphometric parameters in three size classes. The conservative Tukey post hoc test was used to evaluate differences that occurred. Statistical analyses were conducted using Rstudio software, version 1.1.383 (R Core Team 2017) and were considered significant at $(\mathrm{P}<0.05)$. 


\section{Results}

The present study contributes to improved biological knowledge on the greater forkbeard, P. blennoides, inhabiting the waters off the Algerian coast. According to our observations, this species was scarce, and the main common commercial sizes landed in Algerian ports and markets were juvenile and medium, while large specimens were rare.

\section{Morphology}

The digestive tract consisted of a short, wide esophagus measuring $1.09 \pm 0.39 \mathrm{~cm}$, which flared into a well-differentiated cecal stomach $(3.66 \pm 1.18 \mathrm{~cm})$, an intestine $(19.76 \pm 8.90 \mathrm{~cm})$, and a pyloric cecum with an average size of $28.88 \pm 4.85$ (Fig. 2). There was a pocket at the elbow joint between the main cardiac part of the stomach and the distal pyloric part. At the

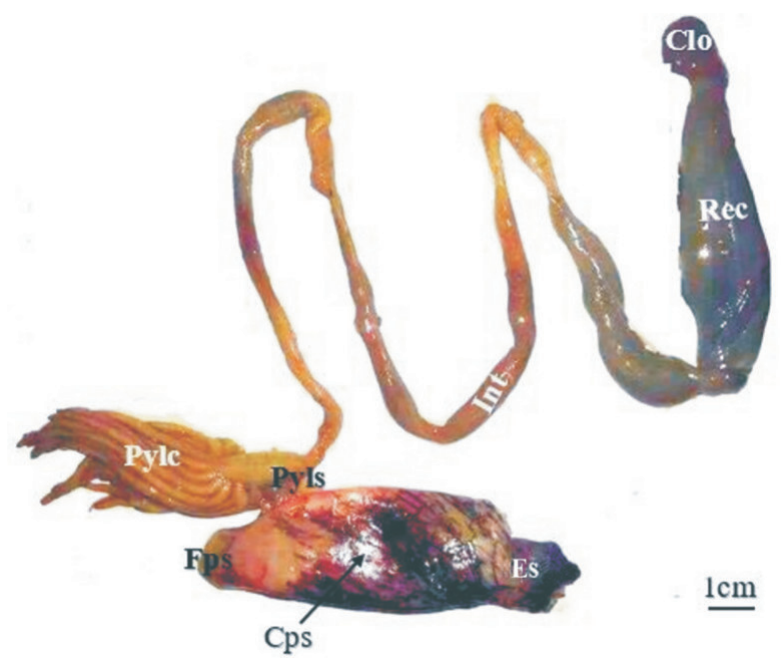

Figure 2. Macroscopic morphology of the digestive tract of $P$. blennoides. Es. - Esophagus; Cps. - Cardiac part of stomach; Fps. - Fundic part of stomach; Pyls. - Pyloric part of stomach; Pylc. Pyloric ceca; Int. - Intestine; Rec. - Rectum; Clo. - Cloaca.

posterior part of the pyloric cecal inlets, the intestine formed a distal loop, then moved forward and formed a second loop. Just behind the second loop, the intestine widened to form a rectum $(2.94 \pm 2.05 \mathrm{~cm})$ that led to the cloaca at the entrance to the genital excretory tract (anal orifice). The liver was very bulky, with very fine filaments attached to the stomach and the gonads, and the spleen was diffused in the liver. A small transparent pouch containing bile was also present, but this was not always visible at each dissection. We also distinguished a sac at the elbow between the cardiac portion of the stomach and the pyloric portion, which narrowed. Just behind the second loop, the intestine widened to form a rectum that opened into the anterior part of the cloaca at the entry point of the genital-excrete canal. In P. blennoides, the pale pink liver was bilobed, and the ventral lobe was larger than the dorsal lobe, with an ovoid gallbladder. The spleen was garnet in color, small, and especially difficult to dissociate from the liver. The spleen was weighed simultaneously with the liver.

Specimens of P. blennoides had a standard length of $21.18 \pm 6.91 \mathrm{~cm}$ and an average weight of $89.25 \pm$ 138.32 g. Overall, stomach, liver, and body mass increased significantly with fish size $(\mathrm{P}<0.001)$ (Table 1$)$. The mean values for liver and stomach weights were $3.33 \pm 7.38$ and $2.22 \pm 4.08 \mathrm{~g}$, respectively. The hepatosomatic index presented an average value of $3.06 \pm 8.61 \%$. It varied significantly with size $(\mathrm{P}<0.001)$ classes observed between small and medium individuals, while no significance was noted in small and large specimens $(\mathrm{P}=0.091)$ or between medium and large specimens $(\mathrm{P}=0.974)$ (Table 1$)$. However, medium specimens appeared to be in good condition in term of energy storage, which indicated recent feeding activity with a maximum average number of $4.08 \pm 11.76 \%$.

The relationship between the total length with liver weight and the stomach weight are presented in Fig. 3. The linear regression model for total length and liver weight determined $67.2 \%$ of the smooth distribution with a moderately positive relationship $(\mathrm{r}=0.451$, $(\mathrm{P}<$ 0.001 ), where a large scatter of points (significant dispersion) was mainly observed in large individuals. The total length (TL) and stomach weight $\left(\mathrm{W}_{\mathrm{st}}\right)$ relationship was described by $71.3 \%$, and a moderate positive relationship was observed in the large category $(\mathrm{r}=0.508, \mathrm{P}$ $<0.001)$. According to this model, there was no actual regression since the points had a random distribution concentrated on the medium size class $(20-30 \mathrm{~cm})$.

The intestinal quotient was low (IQ $<1$ ) indicating a carnivorous feeding habits (Table 2). The highest 

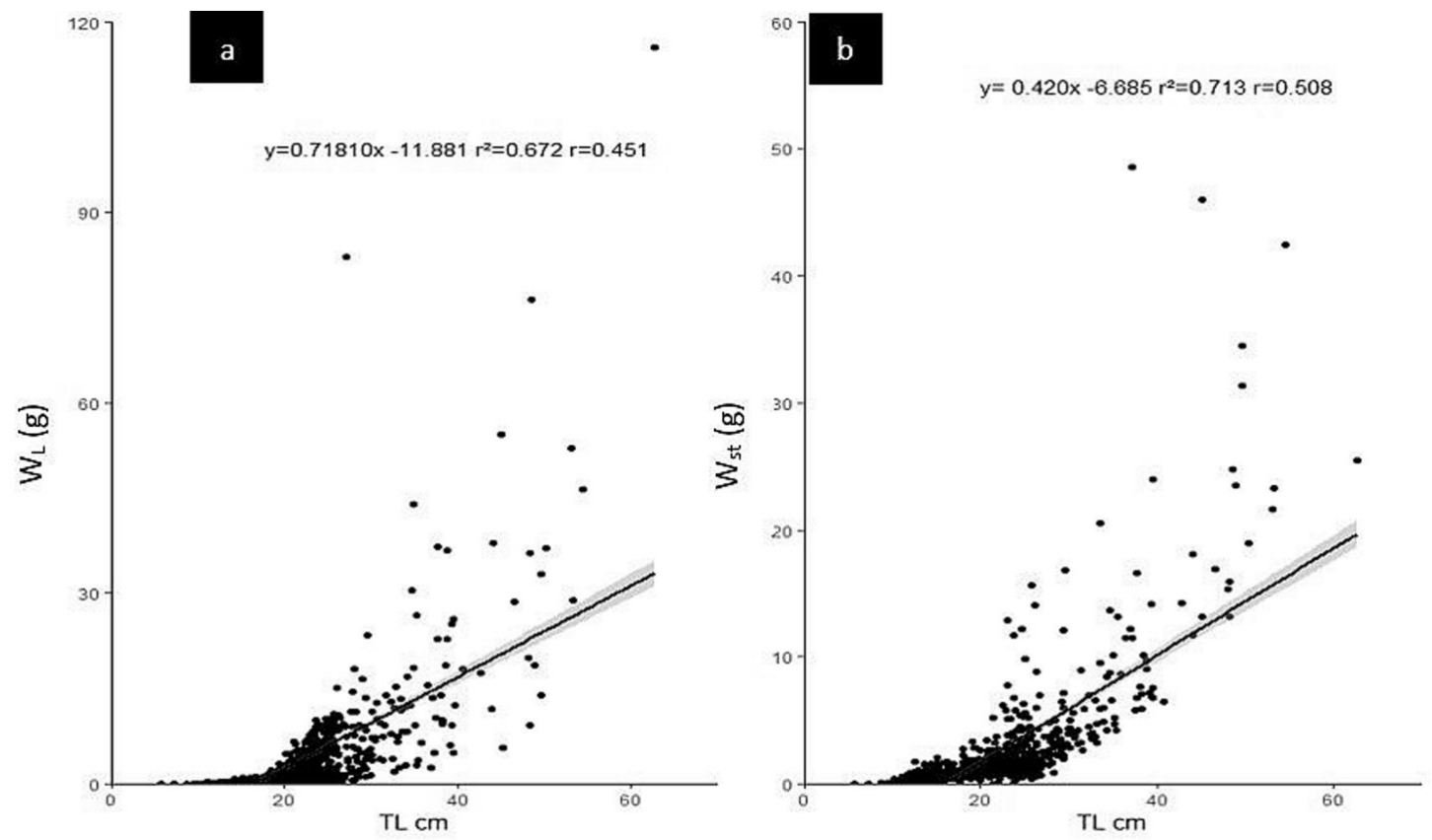

Figure 3. Linear regression model of liver weight WL (a) and stomach weight Wst (b) with fish size of P. blennoides.

Table 1

Hepatosomatic index and weight variation of the body, stomach, and liver of P. blennoides. N - number of samples; HSI Hepatosomatic index; TW - total weight; $\mathrm{W}_{\mathrm{st}}$ - stomach weight; $\mathrm{W}_{\mathrm{L}}$ - liver weight

\begin{tabular}{|c|c|c|c|c|c|}
\hline \multirow[b]{2}{*}{ Parameters } & \multicolumn{3}{|c|}{ Total length (cm) } & \multirow[b]{2}{*}{ P-value } & \multirow[b]{2}{*}{ Total } \\
\hline & $<20$ & $20-30$ & $>30$ & & \\
\hline $\mathrm{N}$ & 413 & 531 & 75 & & \\
\hline HIS (\%) & $1.61 \pm 1.07$ & $4.08 \pm 11.76$ & $3.85 \pm 2.11$ & $<0.001$ & $3.06 \pm 8.61$ \\
\hline TW (g) & $25.42 \pm 14.64$ & $87.08 \pm 32.14$ & $456.09 \pm 308.93$ & $<0.001$ & $89.25 \pm 138.32$ \\
\hline $\mathrm{W}_{\text {st }}(\mathrm{g})$ & $0.70 \pm 0.47$ & $2.07 \pm 1.86$ & $11.68 \pm 9.94$ & $<0.001$ & $2.22 \pm 4.08$ \\
\hline $\mathrm{W}_{\mathrm{L}}(\mathrm{g})$ & $0.50 \pm 0.52$ & $3.42 \pm 4.52$ & $18.24 \pm 18.22$ & $<0.001$ & $3.33 \pm 7.38$ \\
\hline
\end{tabular}

Table 2

Variation of morphometric measurement in P. blennoides. Means $\pm \mathrm{SD}$; $\mathrm{N}$ - number of samples; $\mathrm{R}$ - ratio between the length of the digestive tract and body weight $\left(\mathrm{L}_{\text {tract }} / \mathrm{TW}\right)$; IQ - intestinal quotient; $\mathrm{L}_{\text {tract }}$ - length of the digestive tract; $\mathrm{L}_{\mathrm{oso}}-$ length of the esophagus; $\mathrm{L}_{\mathrm{st}}$ - length of the stomach; $\mathrm{L}_{\text {int }}$ - length of the intestine; $\mathrm{L}_{\text {rect }}$ - length of the rectum; $\mathrm{N}_{\text {Ceacum }}$ - Number of pyloric ceca

\begin{tabular}{|c|c|c|c|c|c|}
\hline \multirow[b]{2}{*}{ Parameters } & \multicolumn{3}{|c|}{ Total length (cm) } & \multirow[b]{2}{*}{ P-value } & \multirow[b]{2}{*}{ Total } \\
\hline & $<20$ & $20-30$ & $>30$ & & \\
\hline $\mathrm{N}$ & 3 & 16 & 10 & & \\
\hline $\mathrm{R}$ & $0.46 \pm 0.12$ & $0.31 \pm 0.10$ & $0.13 \pm 0.02$ & $<0.001$ & $0.26 \pm 0.14$ \\
\hline IQ & $0.67 \pm 0.14$ & $0.67 \pm 0.09$ & $0.82 \pm 0.13$ & 0.0141 & $0.72 \pm 0.13$ \\
\hline $\mathrm{L}_{\text {tract }}(\mathrm{cm})$ & $17.47 \pm 5.05$ & $20.36 \pm 5.18$ & $39.53 \pm 4.99$ & $<0.001$ & $26.67 \pm 10.76$ \\
\hline $\mathrm{L}_{\mathrm{oso}}(\mathrm{cm})$ & $0,83 \pm 0,51$ & $0.96 \pm 0.22$ & $1.37 \pm 0.45$ & $0.012 * *$ & $1.09 \pm 0.39$ \\
\hline $\mathrm{L}_{\mathrm{st}}(\mathrm{cm})$ & $2,635 \pm 0,31$ & $3.06 \pm 0.06$ & $4.93 \pm 0.97$ & $<0.001$ & $3.66 \pm 1.18$ \\
\hline $\mathrm{L}_{\text {int }}(\mathrm{cm})$ & $12.50 \pm 2.60$ & $14.49 \pm 3.25$ & $29.85 \pm 6.54$ & $<0.001$ & $19.76 \pm 8.90$ \\
\hline $\mathrm{L}_{\text {rect }}(\mathrm{cm})$ & $1.50 \pm 1.73$ & $2.93 \pm 1.45$ & $3.38 \pm 2.78$ & 0.393 & $2.94 \pm 2.05$ \\
\hline $\mathrm{N}_{\text {Ceacum }}$ & $24.67 \pm 4.62$ & $28.88 \pm 5.24$ & $31.43 \pm 2.51$ & 0.116 & $28.88 \pm 4.85$ \\
\hline
\end{tabular}


value (IQ $=0.82 \pm 0.13$ ) was observed in the large specimens, and it varied significantly $(\mathrm{P}=0.014)$ with size. The difference was observed between medium and large $(\mathrm{P}=0.013)$ specimens, but it was not significant between small and large $(\mathrm{P}=0.143)$ or medium and small $(\mathrm{P}=0.997)$ sizes. The ratio $(\mathrm{R})$ between digestive tract length and total weight decreased with size and varied significantly among the three size classes $(\mathrm{P}<0.001)$. Also, the length of the digestive tract differed significantly $(\mathrm{P}<0.001)$ among fish sizes. This difference occured in medium and large sizes and small and large individuals $(\mathrm{P}<0.001)$. We found no significant difference in the length of the digestive tract between small and medium individuals $(\mathrm{P}=0.643)$. A significant difference $(P=0.012)$ was observed in esophagus length only between medium and large sized specimens $(\mathrm{P}=0.017)$, whereas no differences were noted between small and medium sizes $(\mathrm{P}=0.822)$ or between small and large specimens $(\mathrm{P}=0.063)$. Stomach size increased in length with significant changes $(\mathrm{P}$ $<0.001$ ) between two size categories (medium and large and small and large: $\mathrm{P}<0.001)$. No significant differences in stomach length between the two small and medium classes were observed $(\mathrm{P}=0.628)$. In addition, we also observed a significant increase in gut length as a function of fish size $(\mathrm{P}<0.001)$ between small and large and between medium and large specimens. On the other hand, no significant difference in rectal length or the number of pyloric ceca were observed (Table 2).

\section{Histology}

The different digestive tract parts of the target species were sectioned transversally. The first sections of the esophagus structure showed three characteristics folds with three layers: the mucosa composed of epithelium, the large muscularis, and an external tunic composed of densely packed connective tissue (Fig. 4a). The transversal section through the esophagus-stomach transition showed a vascularized muscularis mucosa containing small blood vessels, capillaries, and a lamina propria (Chorion) (Fig. 4b). The esophageal villi (Fig. 4c) was composed by the muscularis, the mucosa, the lamina propria, and an external tunic (Fig. 4d).
The histological study of the stomach was performed on different regions: the cardia, pylorus, and fundus. The cardiac part of the stomach presented a fold with muscular tissue (Fig. 4e). The longitudinal muscularis composed by the circular muscularis was observed in the basal zone (Fig. 4f), while longitudinal fibers were located in the apical area (Fig. 4g). The pyloric part of the stomach had five layers (Fig. 4h). The mucosa was composed of a stratified squamous epithelium (Fig. 4i). The mucosa layer contained many acinus glands (Fig. 4j) for digestion. It was surrounded by a thin layer of sub-mucosal tissue and a muscularis mucosa. This region was well defined by longitudinal fibers composing the muscularis circularis and muscularis longitudinalis ending with the serosa layer. The transversal section through the fundic part of stomach (Fig. 4k) appeared as a round disk without light at the center. A large layer of muscularis and epithelial cells, containing acinus glands, composed this structure.

In the intestines (Figs. 4l-4m) the mucosa was folded longitudinally, and the epithelial cells were covered with slightly elevated villi (Fig. 4n). Glandular cells were observed in the light of these villi (Fig. 4o). The serosa consisted of a thin layer of collagen and a simple squamous epithelium. The pyloric ceca appeared (Fig. 4p) as tufts blinded sphincter ducts associated with the anterior intestine, and pancreatic tissue was lodged between the ducts. The mucosa of the pyloric ceca was similar to that of the intestine and no specific cell type was associated with this organ.

\section{Histological changes}

Some histological changes were observed in different organs of $P$. blennoides (Fig. 5). Abnormalities were observed in the intestine and the liver. A nematode was found in the intestinal structure, and it was identified as Anisakis simplex. This nematode was characterized by a pair of clover-shaped lateral chords, eosinophilic renette cells (excretory organ), and a gut consisting of high columnar cells (Fig. 5a-5b). Unidentified nematodes were also located in the liver (Fig. 5c). A cyst was found in a specimen of $38 \mathrm{~cm}$ in total length (caught on 


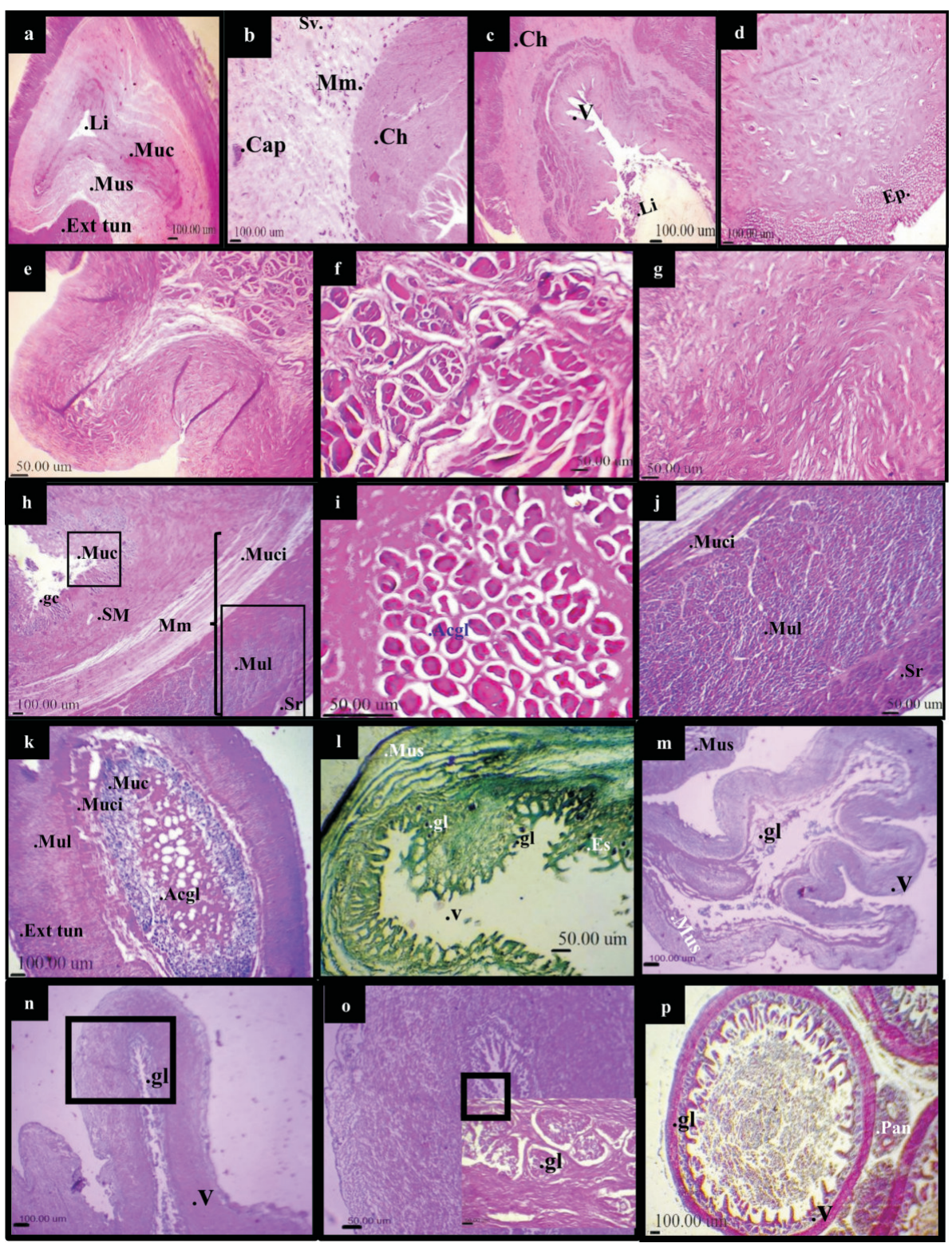

Figure 4. Histological sections of the digestive tract of the adult P. blennoides. Ext tun. - External tunic; Ext tun. - External tunic; Mus.Muscularis; Muc. -Mucosa; Li.- Light; Cap.- Capillaries; Sv. - Small blood vessels; Mm.-Muscularis-mucosa;Ch. -Chorion or lamina propria; V.- Villi;Ep.-Epithelium; SM.- Sub-mucosa;Muci.-Muscularis circularis; Mul.-Muscularis longitudinalis; Sr.-Serosa;gc.-goblet cell;Acgl.- Acinus gland; gl.-glands;Es.-Surface epithelial cells; Pan.-Pancreas a. General view of an esophagus; b. Cross-section at the esophagus-stomach transition part; c. Esophageal villosity; d. External tunic of the esophago-stomach transition (a, b, d: scale - GX40, stain - H\&E, TL - $53.3 \mathrm{~cm}$, TW - $1033.40 \mathrm{~g}$, caught 26/09/2014); e. Section of the cardiac part of the stomach; f. Longitudinal muscularis in the cardiac part of the stomach; g. Circular muscularis through the cardiac part of the stomach (e, f, g: scale - GX100, TL - 53.3 cm, TW - 1033.40 g caught 26/09/2014, stain - H\&E); h. Section through the pyloric part of the stomach with stratified squamous epithelium, caliciform cells and submucosa (GX40, TL - $48.1 \mathrm{~cm}$, TW - 734.62 g, caught 13/07/2014, stain - H\&E); i. Acinus gland in squamous epithelium (GX400, TL - $48.1 \mathrm{~cm}$, TW - $734.62 \mathrm{~g}$, caught 13/07/2014, stain - H\&E); j. Musclaris and serosa layer (GX100, TL - 48.1 cm, TW - 734.62 g, caught 13/07/2014, stain - H\&E); k. Section through the fundus (GX40, TL - 48.6 cm, TW - 957.69g, caught10/02/2015, stain - H\&E); 1. Section through the intestine and demonstration of epithelial cells with intestinal villi (GX100, TL $48.6 \mathrm{~cm}$, TW - $957.69 \mathrm{~g}$, caught 10/02/2015, stain - Trichrome of Masson); m. Section through the intestine and demonstration of epithelial cells with intestinal villosity (GX40, TL - 38cm, TW - 372.27g, WL - 13.91g, caught 17/05/2017, stain - PAS); n. Intestinal Villosity (GX40, TL - 38cm, TW - 372.27g, WL - 13.91g, caught 17/05/2017, stain - PAS); o. Intestinal Villosity (GX100, TL - 38cm, TW - 372.27g, WL - 13.91g, caught 17/05/2017, stain - PAS) with zoom on glandular cells GX400. p. Section at the pyloric cecum (GX40, TL - 48.6 cm, TW - 957.69 g, caught 10/02/2015, stain - H\&E). 


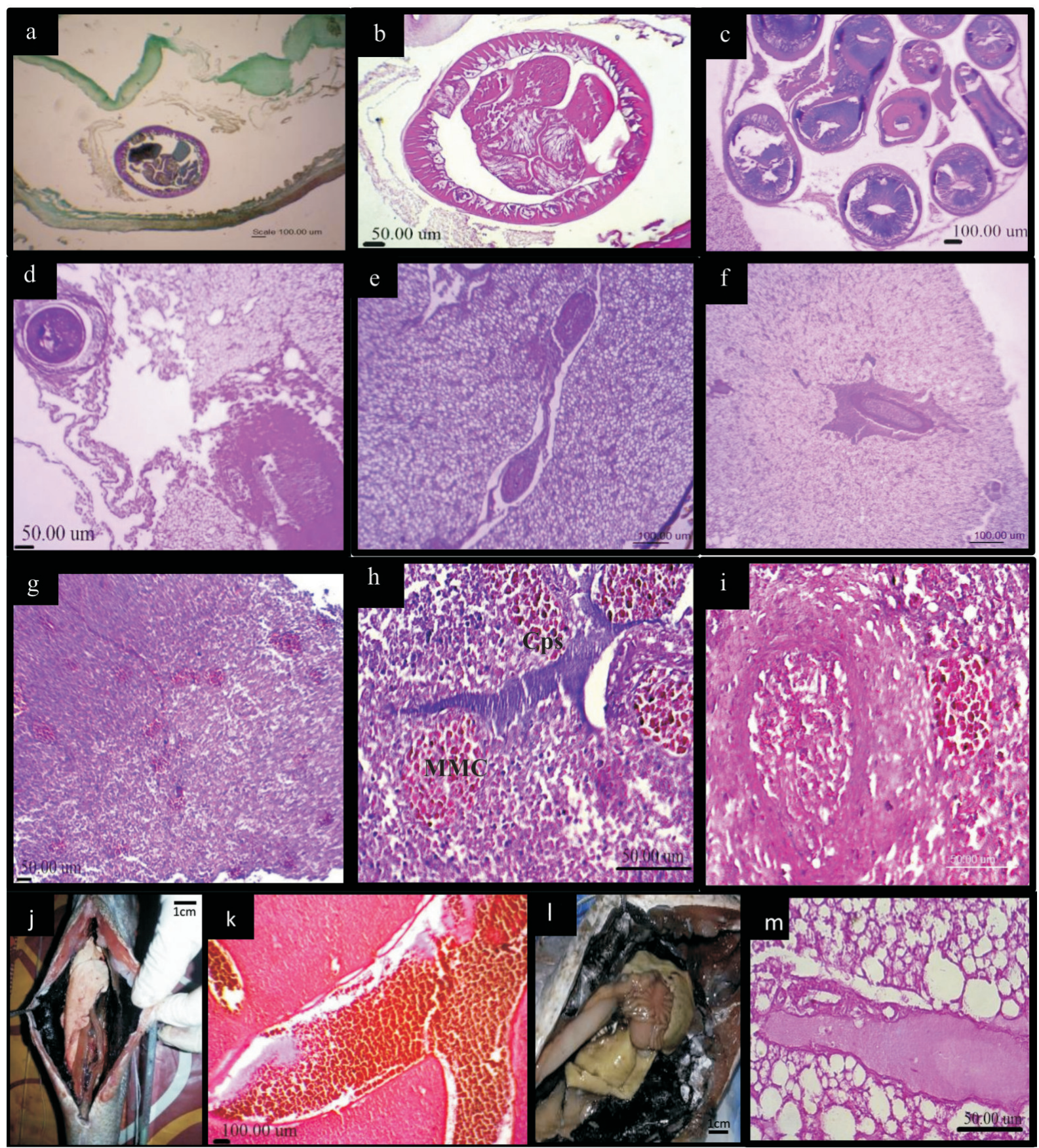

Figure 5. Histological sections through the intestine, liver, and spleen of $P$. blennoides after natural exposure to parasitism and contaminants. a. General view of a nematode in an intestinal portion stain - trichrome of Masson (scale - Gx40); b. A. simplex in the intestine of a female fish (scale - Gx100, TL - $48.6 \mathrm{~cm}$, TW - $957.69 \mathrm{~g}$, $\mathrm{W}_{\mathrm{L}}-76.24 \mathrm{~g}$ date of caught 10/02/2015, stain - H\&E); c. Nematoda in the liver (GX40, TL - $38 \mathrm{~cm}, \mathrm{TW}-372.27 \mathrm{~g}, \mathrm{~W}_{\mathrm{L}}-13.91 \mathrm{~g}$, caught 17/05/2017, stain - PAS); d. Different abnormalities detected in liver (cyst, parasite, steatosis) (GX100); e. Cysts in the liver with hepatic steatosis (Gx100, TL - $38 \mathrm{~cm}$, TW - $372.27 \mathrm{~g}, \mathrm{~W}_{\mathrm{L}}-13.91 \mathrm{~g}$, caught 17/05/2017, stain - PAS); f. Lesion in the liver (GX40, TL - $38 \mathrm{~cm}$, TW - 372.27 g, W $-13.91 \mathrm{~g}$, caught 17/05/2017, stain - PAS); g. Histological section through the spleen (GX100, TL - $48.6 \mathrm{~cm}$, TW - $957.69 \mathrm{~g}, \mathrm{~W}_{\mathrm{L}}-76.24 \mathrm{~g}$, caught 10/02/2015); h. Melanomacrophage centers (MMC) in the spleen of adult specimen (GX400, TL - $48.6 \mathrm{~cm}$, TW - 957.69 g, W $\mathrm{L}-76.24 \mathrm{~g}$, caught 10/02/2015) (Cps - Splenic parenchyma partitions); i. Blood vessel (G x40, stain - PAS); j. Macroscopic image of a healthy liver $\left(\mathrm{TL}-49.7 \mathrm{~cm}, \mathrm{TW}-737.16 \mathrm{~g}, \mathrm{~W}_{\mathrm{L}}-\right.$ 13.91 g caught 21/03/2016); k. Microscopic image of a healthy liver (GX40, H\&E); l. Macroscopic image of abnormal liver with greenish-yellow color (TL $-25 \mathrm{~cm}$, TW $-84.92 \mathrm{~g}, \mathrm{~W}_{\mathrm{L}}-1.75 \mathrm{~g}$, caught 6/01/2015); m. High incidence of hepatic steatosis and presence of hepatocyte lipids (GX400, H\&E). 
May 17, 2017) with hepatic steatosis (Fig. 5d). Other lesions were also visible in the same individual (Figs. 5e-5f). However, no specific abnormalities were observed in the spleen of this infested individual (Fig. 5g). The spleen was highly pigmented because of the degradation of red blood cells (Fig. 5i). It was surrounded by a thin capsule of a conjunctive nature from which fine partitions penetrated the splenic parenchyma (Fig. 5h). A case of melanomacrophage centered through the spleen of the same individual with the A. simplex in its intestine (Fig. 5h) was noted. In the liver of $P$. blennoides, the bile ducts, hepatic arteries, and veins were grouped into "hepatic triads" in a sheet of connective tissue (Fig. 5k). At dissection, the liver was normal with a pinkish colour (Fig. 5j), while the abnormal liver appeared greenish-yellow (Fig. 5l). Microscopically, the disturbance was visible by the presence of lipid lacuna leading to fatty liver and lipidic infiltration indicating an inflammation called hepatic steatosis (Fig. 5m).

\section{Discussion}

\section{Morphohistology}

Almost nothing is known about many fish species in deep Mediterranean waters including those living on slopes. Baseline morphological knowledge has not yet been recorded for most of these fishes. However, the morphohistology characterization of fish digestive tracts is fundamental to understand feeding physiology (Canan et al. 2012). In order to define the feeding habits of fishes, it is important to analyses the morphometric parameters of their digestive tracts (Becker et al. 2010).

In this study, the intestinal quotient (IQ) of $P$. blennoides was low and was within the expected range for carnivorous species. Ward-Campbell et al. (2005) state that an intestinal quotient value below one is indicative of a carnivorous diet. Menin and Mimura (1992) report low values in Hoplias malabaricus (Bloch) and Becker et al. (2010) note an equivalent $\mathrm{IQ}=0.51$ for the same species. Moreover, there is a correlation between the structures of the digestive apparatus and the feeding habits of fishes (Fugi et al. 2001, Ward-Campbell et al. 2005). The quotient digestive tract length-fish weight is low at an average value of $\mathrm{R}=0.26 \pm 0.14$. As reported by Hidalgo et al. (1999) and Becker et al. (2010), this quotient is low for carnivorous species and high for omnivorous and herbivorous species.

Gastrointestinal tract structure can be affected by feeding habits, and it varies substantially in intestinal length and area (Buddington et al. 1987). Moreover, in carnivorous fish the intestine is a complex multifunctional organ with a highly variable structure that reflects phylogenetic diversity (Buddington et al. 1997). The diet of $P$. blennoides is mainly composed by crustacean and fishes in the Mediterranean (Sorbe 1977, Sartor 1995, Morte et al. 2002) and the Atlantic (Mauchline and Gordon 1984). According to our investigations, the intestine length of $P$. blennoides is short, and it increases allometrically with body size, which reflects its carnivorous feeding strategy. It is commonly emphasized that herbivorous fishes have longer digestive tracts than carnivorous fishes (Kramer and Bryant 1995). According to Buddington et al. (1997), the intestines of carnivorous fish have evolved for processing a highly digestible, nutrient dense diet that is high in protein and low in carbohydrates.

Anatomically, digestive tracts vary according to diet type. Phytophagous fishes, such as Sarpa salpa (L.), have long intestines (S. Amira, personal communication). This is also the case with Boops boops (L.), which is omnivorous (Derbal and Kara 2008). This is different in carnivorous fish, and their digestive tracts seem to be shorter, as is observed in Phycis phycis (L.) and P. blennoides inhabiting the waters off the Algerian coast (Z. Alioua, personal observation). However, prey size increases with predator size (Alioua et al. 2018), and digestive tracts also become larger with size. Indeed, the surface area that hosts the food bolus widens, and the intestine becomes longer to increase capacity to ingest prey and to create a larger surface area for nutrient absorption. The number of pyloric ceca also increases and facilitates greater digestive activity in large specimens. 
The histological structure of fish digestive systems has been described (Wilson and Castro 2011), and the anatomy and morphology of their gastrointestinal tract follows the same basic plan as in other vertebrates, but there are degrees of variation reflected in phylogeny and ontogeny, diet composition, and the natural environments of fishes (Wilson and Castro 2011). The esophagus is lined with a mucosal layer of epithelial mucous cells that protect it from chemical and mechanical damage, act as a lubricant to facilitate the passage of food, and have a role in osmoregulation (Humbert et al. 1984, Shephard 1994).

Anatomically, the junction of the esophagus and stomach is generally not clearly demarcated (Kapoor et al. 1975). However, the beginning of the stomach can be observed histologically, as the epithelium changes into the columnar mucosal cells of the stomach, and gastric glands appear. The powerful gastric muscularis of the carnivorous $P$. blennoides was well developed. It consisted of unstriated muscle fibers arranged in two layers (circular and longitudinal). These results are consistent with those of carnivorous species such as Seriola dumerili (Risso) (Grau et al. 1992), the eel, Anguilla anguilla (L.) (Ostos Garrido et al. 1996), and the cod, Gadus morhua L. (Morrison 1987). The muscularis mucosa is found in the pyloric portion of the stomach of P. blennoides, whereas it is absent from the cardio-fundic part of the stomach. Reifel and Travill (1977) state that the combination of well-developed musculature and the absence of the gastric glands in seven teleost species could indicate that the primary function of the pyloric region of the stomach is the mixing and pushing the food distally. The mucosa of the pyloric ceca is similar to the intestine, and no special cell types or glands are associated with this organ (Buddington et al. 1987), although there are fewer goblet cells in the ceca (Hossain and Dutta 1996). Thus, ceca are an adaptation for increasing intestinal surface area without increasing the length or thickness of the intestine itself (Buddington et al. 1987). In addition, the primary function of the intestine is the completion of the digestive processes started in the stomach and the absorption of nutrients.
Adult Gadidae have the most differentiated digestive tract in Teleosteii (Morrison 1993), and it changes with ontogeny (Wilson and Castro 2011). In this context, the histological feature of the digestive tract of P. blennoides from the Algerian coast was studied in adult specimens only. In addition, this species is characterized by a high trophic level (Alioua et al. 2018) closely related to its carnivorous feeding habits and its adaptive capacity to ingest voluminous prey thanks to the folds of esophagus structure. Morrison (1987) describes these same folds in the esophageal structure of Gadus morhua. However, the gastrointestinal system observed in $P$. blennoides is anatomically and histologically similar to the digestive system of $G$. morhua with the absence of muscularis mucosa in the beginning of the esophagus structure. However, muscularis mucosa appears in the esophagus-stomach transition, with a dense structure in the middle of pyloric ceca. Some authors suggest that there is no correlation between the number of pyloric ceca or the size and length of the intestine or the type of feeding. According to Carrassón and Matallanas (1994) and Carrassón et al. (2006), who examined the histology of the digestive tract of Dentex dentex (L.), it would seem that the number and shape of pyloric ceca is a phylogeny related trait rather than a feeding related trait, as previously reported by Geistdoerfer (1981). In contrast to Buddington et al. (1987), this relationship was confirmed in the present study. With the exception of a few indications relating to the histology of the digestive tract of Gadiformes, notably G. morhua and Lota lota (L.), a very brief comparison will undoubtedly shed light on the anatomical and tissular structures.

The hepatosomatic index (HSI), which describes the energy stored by fish, is a good indicator of recent dietary activity (Tyler and Dunn 1976). Delahunty and de Vlaming (1980) mention that HSI does not change over the range of body weight, suggesting that HSI is an appropriate expression of liver size. When food is plentiful and conditions are favorable, hepatosomatic values increase. In the current study, the highest hepatosomatic index of P. blennoides was noted in medium specimens. However, large 
individuals showed a decrease in this index, which can be influenced by seasonal cycles and unfavorable environmental conditions.

The liver is a gland with excretory functions and a detoxification organ, the form of which varies from one species to another. In P. blennoides the liver is bilobed, and the ventral lobe is larger than the dorsal lobe with an ovoid gallbladder, containing bile. The whole gland is a network of liver blades with a tortuous arrangement, anastomosed, and relatively thick. The spaces between these blades are occupied by a network of blood sinusoids draining blood from the hepatic artery.

$P$. blennoides has pancreatic tissue between the pyloric ceca and the ovoid gallbladder. Similarly to $G$. morhua, the pancreatic tissue was observed by Morrison (1987) between the pyloric ceca and around the bile duct and pancreatic ducts. Also according to this author, it covers one side of the gallbladder and follows the blood vessels in the mesenteric tissue near the gut.

In Teleosteans, the spleen is located on either the right or left side of the stomach. In P. blennoides, the spleen is easily observed because of the contrast of its red-brown color against the pale pink of the liver. It is often found on the right side and is difficult to detach from the liver, as it is connected to it by transparent filaments, penetrating the blood-soaked splenic parenchyma.

\section{Histopathology}

As with most animal species, various diseases occur in fish and their sources are as numerous as the diseases themselves. Indeed, viral, bacterial and fungal infections, infections of parasitic origin or pollution can affect fish at different levels (skin, fins, gills, digestive system, etc.) and impact human health. Many zoonoses are transmitted to humans through food. However, fish are a potential source of zoonoses, particularly through the transmission of parasites. Among them, Anisakis simplex is one of the most important nematodes in terms of public health (Orain 2010). From a histological section of $P$. blennoides gut, A. simplex was observed in this study. In Phycidae species, Anisakis that cause digestive parasitosis and allergies (Audicana and Kennedy 2008) was also found in P. phycis and P. blennoides from the Portuguese (Valero et al. 2006) and Tunisian coasts (Farjallah et al. 2006). Moreover, Morrison (1987) also reports an unidentified nematode in the digestive tract of G. morhua.

In the Bay of Biscay, some abnormalities are reported in the liver and gonads of deep-water fish species caught between 700 and 1,400 m. A wide variety of inflammatory and degenerative lesions such as foci of cellular alteration in the black scabbardfish, Aphanopus carbo Lowe, and the orange roughy, Hoplostethus atlanticus Collett (Feist et al. 2015). Additionally, one case of hepatocellular adenomas was detected in $H$. atlanticus. These authors also found granuloma and lymphocytic infiltrations in the liver of $P$. blennoides and cases of ovotestis in $A$. carbo (Feist et al. 2015). The hepatic steatosis of $P$. blennoides found in the current study could likely be related to acute and chronic toxicity in response to various stresses associated with long-term exposure to carcinogenic compounds. In the Balearic Sea, Rotllant et al. (2002) also identified an oocyte in testicular tissue of $P$. blennoides. In addition, intersex was found in its congener P. phycis from the Portuguese coast (Vieira et al. 2016). These changes could also be related to persistent organic pollutants that have harmful effects on animals and humans. Specialists on hepatic changes explain these in tropical ecosystems by the appearance of three different cell types. These cell types are involved in carcinogens in the livers of fish such as hepatocytes, bile epithelial cells, and sinusoidal endothelial cells (Almeida and Oliveira Riberio 2014). In addition, cysts of unknown etiology are frequently found structures embedded in the gill primary lamellae of gadiform fishes (Munday and Brand 1992). According to Almeida and Riberio Oliveira (2014), lipid storage is described as a defense mechanism against the presence of fat-soluble contaminants. Feist et al. (2015) published a histopathological assessment of several deep-sea fish species in the Atlantic Ocean, including $P$. blennoides, to test the effect of anthropogenic 
contaminants on the liver and gonads only. On the Algerian coast, this is the first histopathological assessment in organs of $P$. blennoides. Histopathological lesions in the liver indicated exposure to anthropogenic contaminants that can disrupt the biological balance of the environment and impact fish stock integrity.

\section{Conclusion}

The present study suggests that the characteristics of the gastrointestinal tract of $P$. blennoides are compatible with its carnivorous feeding behavior. However, further studies should be conducted to better understand the process of digestion and food absorption of this fish and to integrate the biochemical approach of enzymology. Concerning Nematodes, it would be advisable to carry out a more in-depth study on the species of Nematodes that establish in this host, to better understand its parasitic infestation.

There is evidence of the presence of pollutants in the biota of Algerian deep-waters, probably at higher levels than one might imagine, and their arrival at great depths would be rather unexpected. Thus, the identification of the origin of the pathological assessment by chemical studies could probably clarify the type of pollution and its nature and better assess the environment of $P$. blennoides habitats.

Acknowledgments. We are grateful to fishermen of the region and to Boufekane Billel for help in collecting biological material. We also thank anonymous reviewers for their constructive comments and suggestions.

Author contributions. Z.A. performed the sampling, data processing, statistical analysis, and prepared the manuscript; S.A. contributed to collecting and analyzing data and described the micrographs and reviewed the literature; N.S. identified the hepatic steatosis and helped in the preparation of the figures; F.Z.-K. supervised the work and contributed to the description of the histological structures. All authors discussed the results and contributed to the final manuscript.

ORCID ID

Zakia Alioua. (iD https://orcid.org/0000-0003-4868-5080
Soumia Amira. iD https://orcid.org/0000-0001-8377-8763

\section{References}

Al-Abdulahadi H.A. 2005 - Some comparative histological studies on alimentary tract of Tilapia fish (Tilapia spirulis) and sea bream (Mylio cuvieri) - Egypt. J. Aquat. Res. 31: 387-397.

Alabssawy A.N., Khalaf-Allah H.M.M., Gafar A.A. 2019 Anatomical and histological adaptations of digestive tract in relation to food and feeding habits of lizardfish, Synodus variegatus (Lacepède, 1803) - Egypt. J. Aquat. Res. 45: 159-165.

Alioua Z., Amira S., Derbal F., Rachedi M., Bahbah L., Zerouali-Khodja F. 2018 - Diet composition and trophic level of greater forkbeard Phycis blennoides (Gadiform: Phycidae) from the Algerian coast - Croat. J. Fish. 76: 135-144.

Almeida E.A., Oliveira Riberio C.A. 2014 - Pollution and Fish Health in Tropical Ecosystems - Boca Raton: CRC Press.

Audicana M.T., Kennedy M.W. 2008 - Anisakis simplex: From obscure infectious worm to inducer of immune hypersensitivity - Clin. Microbiol. Rev. 21: 360-379.

Becker A.G., Gonçalves J.F., Garcia L.O., Behr E.R., Graça D.L., Kurtz Filho M., Martins T., Baldisserotto B. 2010 Morphometric parameters comparisons of the digestive tract of four teleosts with different feeding habits - Cięnc. Rural 40: 862-866.

Benghali S.M.E.A., Mouffok S., Kherraz A., Boutiba Z. 2014 Some aspects on the reproductive biology of Greater forkbeard Phycis blennoides (Brünnich, 1768) in Western Algerian Coasts (Osteichthyes, Gadidae) - Int. J. Rec. Res. Appl. Stud. 19: 199-206.

Buddington R.K., Chen J.W., Diamond J. 1987 - Genetic and phenotypic adaptation of intestinal nutrient transport to diet in fish - J. Physiol. 393: 261-281.

Buddington R.K., Krogdahl A., Bakke-McKellep A.M. 1997 The intestines of carnivorous fish: structure and functions and the relations with diet - Acta Physiol. Scand. 161 Suppl. 638: 67-80.

Canan B., Nascimento W.S. Do, Silva N.B. Da, Chellappa S. 2012 - Morphohistology of the digestive tract of the damsel fish stegastes fuscus (Osteichthyes: Pomacentridae) Sci. World J. 2012: 9.

Carrassón M., Matallanas J. 1994 - Morphometric characteristics of the alimentary tract of deep-sea Mediterranean teleosts in relation to their feeding habits - Mar. Biol. 118: 319-322.

Carrassón M., Grau A., Dopazo L.R., Crespo S. 2006 A histological, histochemical and ultrastructural study of the digestive tract of Dentex dentex (Pisces, Sparidae) Histol. Histopathol. 21: 579-593. 
Casas J.M., Pińeiro C. 2000 - Growth and age estimation of greater fork-beard (Phycis blennoides Brunnich, 1768) in the north and northwest of the Iberian Peninsula (ICES Division VIIIc and IXa) - Fish. Res. 47: 19-25.

Cohen D.M., Inada T., Scialabba N. 1990 - Gadiform Fishes of the World: An annotated and illustrated catalogue of Cods, Hakes, Grenadiers and other Gadiform fishes known to date - FAO Fisheries Synopsis 125, 10, 442.

Dallarés S., Moyà-Alcover C.M., Padrós F., Cartes J.E., Solé M., Castañeda C., Carrassón M. 2016 - The parasite community of Phycis blennoides (Brünnich, 1768) from the Balearic Sea in relation to diet, biochemical markers, histopathology and environmental variables - Deep-Sea Res. 118: 84-100.

Delahunty G., de Vlaming V.L. 1980 - Seasonal relationships of ovary weight, liver weight and fat stores with body weight in the goldfish, Carassius auratus (L.) - J. Fish Biol. 16: 5-13.

Derbal F., Kara M.H. 2008 - Composition du régime alimentaire du bogue Boops boops (Sparidae) dans le golfe d'Annaba (Algérie) - Cybium 32: 325-333.

Devine J.A., Baker K.D., Haedrich R.L. 2006 -Deep-sea fishes qualify as endangered - Nature 439: 29.

Farjallah S., Ben Slimane B., Blel H., Amor N., Said K. 2006 Anisakid parasites of two forkbeards (Phycis blennoides and Phycis phycis) from the eastern Mediterranean coasts in Tunisia - Parasitol. Res. 100: 11-17.

Feist S.W., Stentiford G.D., Kent M.L., Ribeiro Santos A., Lorance P. 2015 - Histopathological assessment of liver and gonad pathology in continental slope fish from the northeast Atlantic Ocean - Mar. Environ. Res. 106: 42-50.

Fugi R., Agostinho A.A., Hahn N.S. 2001 - Trophic morphology of five benthic-feeding fish species of a tropical floodplain - Rev. Bras. Biol. 61: 27-33.

Geistdoerfer P. 1981 - Morphologie et histologie de l'appareil digestif des Macrouridae (Teleosteens) - Cybium 5: 3-44.

Grau A., Crespo S., Sarasquete M.C., de Canales M.L.G. 1992 - The digestive tract of the amberjack Seriola dumerili, Risso: a light and scanning electron microscope study - J. Fish Biol. 41: 287-303.

Grimes S., Benabdi M., Babali N., Refes W., Boudjellal-Kaidi N., Seridi H. 2018 - Biodiversity changes along the Algerian coast (Southwest Mediterranean basin): from 1834 to 2017: A first assessment of introduced species Mediterr. Mar. Sci. 19: 156-179.

Hidalgo M.C., Urea E., Sanz A. 1999 - Comparative study of digestive enzymes in fish with different nutritional habits. Proteolytic and amylase activities - Aquaculture 170: 267-283.

Hossain A.M., Dutta H.M. 1996 - Phylogeny, ontogeny, structure and function of digestive tract appendages (caeca) in teleost fish - In: Fish Morphology: Horizon of New
Research (Eds) J.S. Datta Munshi, H.M. Dutta, Science Publishers, Lebanon, NH: 59-76.

Humbert W., Kirsch R., Meister M.F. 1984 - Scanning electron microscopic study of the oesophageal mucous layer in the eel, Anguilla anguilla L - J. Fish Biol. 25: 117-122.

Kapoor B.G., Smith H., Verighina I.A. 1975 - The alimentary canal and digestion in teleosts - Adv. Mar. Biol. 13: 109-139.

Kramer D.L., Bryant M.J. 1995 - Intestine length in the fishes of a tropical stream: 2. Relationships to diet - the long and short of a convoluted issue - Environ. Biol. Fish. 42: 129-141.

Macpherson E. 1978 - Regimen alimentario de Phycis blennoides (Brunnich) and Antonogadus megalokynodon Kolombatovic (Pisces: Gadidae) en el Mediterraneo occidental - Investig. Pesq. 42: 455-466.

Marcotrigiano G.O., Storelli M.M. 2003 - Heavy metal, polychlorinated biphenyl and organochlorine pesticide residues in marine organisms: risk evaluation for consumers - Vet. Res. Commun. 27: 183-195.

Massutí E., Morales-Nin B., Lloris D. 1996 - Bathymetric distribution and recruitment patterns of Phycis blennoides (Pisces: Gadidae) from the slope of the northwestern Mediterranean - Sci. Mar. 60: 481-488.

Matarrese A., D’Onghia G., Basanisi M., Mastrototaro F. 1998 - Spawning and recruitment of Phycis blennoides (Brünnich, 1768) (Phycidae) from the north-western Ionian Sea (middle eastern Mediterranean) - Ital. J. Zool. 65: 203-209.

Mauchline J., Gordon J.D. 1984 - Feeding and bathymetric distribution of the gadoid and morid fish of the Rockall Trough - J. Mar. Biol. Assoc. United Kingdom. 64: 657-665.

Menin E., Mimura O.M. 1992 -Anatomia comparativa do intestino de duas espécies de peixes teleósteos de hábitos alimentares distintos - Rev. Ceres. 39: 308-341.

Moranta J., Quetglas A., Massutí E., Guijarro B., Ordines F., Valls M. 2008 - Research trends on demersal fisheries oceanography in the Mediterranean - In: Biological Oceanography Research Trends (Ed.) L.P. Mertens, Nova Science Publishers, Inc., New York: 9-65.

Moranta J., Stefanescu C., Massutí E., Morales-Nin B., Lloris D. 1998 - Fish community structure and depth-related trends on the continental slope of the Balearic Islands (Algerian basin, western Mediterranean) - Mar. Ecol. Prog. Ser. 171: 247-259.

Morrison C. 1993 - The digestive tract of the cod eleutheroembryo ("yolk-sac larva”) and larva - NAFO Scientific Council Studies, 18: 23-24.

Morrison C.M. 1987 - Histology of the Atlantic Cod, Gadus morhua: an atlas, Part one: Digestive tract and associated organs - Can. Spec. Publ. Fish. Aquatic Sci. 98.

Morte M.S., Redón M.J., Sanz-Brau A. 2002 - Diet of Phycis blennoides (Gadidae) in relation to fish size and season in 
the western Mediterranean (Spain) - Mar. Ecol. 23: 141-155.

Munday B.L., Brand D.G. 1992 - Apparently embolic, enigmatic bodies in the gill filaments of perch - Bull. Eur. Assoc. Fish Pathol. 12: 127-130.

Orain D. 2010 - Apport de l'histologie dans la détection d'Anisakis simplex et de Kudoa Sp. dans les poissons et les matičres premičres utilisées dans l'industrie ou dans les produits finis. These d'exercice, Medecine veterinaire, Toulouse 3, 2010, $93 \mathrm{f}$.

Ostos Garrido M. V., González Oller C., Abaurrea Equisoain M.A. 1996 - Effect of diet on gastric mucosa cells in the European eel (Anguilla anguilla L.). Histochemical and ultrastructural study - Micron 27: 25-34.

R Core Team. 2017 - R: A language and environment for statistical computing - R Foundation for Statistical Computing, Vienna, Austria.

URL https://www.R-project.org/.

Ray A.K., Ringø E. 2014 -The Gastrointestinal tract of fish In: Aquaculture Nutrition (Eds) D. Merrifield, R. Einar R., John Wiley \& Sons, Ltd, Chichester: 1-13.

Reifel C.W., Travill A.A. 1977 - Structure and carbohydrate histochemistry of the intestine in ten teleostean species J. Morphol. 152: 303-314.

Romdhani A., Ktari M.-H. Dufour J.-L., Mahe K., Francour P. 2016 - Growth and age estimation of the greater forkbeard, Phycis blennoides (Actinopterygii: Gadiformes: Phycidae), from the Gulf of Tunis (central Mediterranean) - Acta Ichthyol. Piscat. 46: 25-32.

Rotllant G., Moranta J., Massutí E., Morales-Nin B. 2002 Reproductive biology of three gadiform fish species through the Mediterranean deep-sea range (147-1850 m) - Sci. Mar. 66: 157-166.

Sartor P. 1995 - Regime alimentare di osteitti Gadiformi nel mar Tireeno settentrionale - Atti Soc. Tosc. Sci. Nat., Mem., Serie B, 102: 59-67.

Shephard K.L. 1994 - Functions for fish mucus - Rev. Fish Biol. Fish. 4: 401-429.
Solé M., Hambach B., Cortijo V., Huertas D., Fernández P., Company J.B. 2009 - Muscular and hepatic pollution biomarkers in the fishes Phycis blennoides and Micromesistius poutassou and the crustacean Aristeus antennatus in the Blanes Submarine Canyon (NW Mediterranean) - Arch. Environ. Contam. Toxicol. 57: 123-132.

Sorbe J.C. 1977 - Regime alimentaire de Phycis blennoides (Brunnich 1768) dans le sud du Golfe de Gascogne - Rev. Trav. Inst. Pęches Marit. 41: 271-281.

Stentiford G.D., Bignell J.P., Lyons B.P., Feist S.W. 2009 Site-specific disease profiles in fish and their use in environmental monitoring - Mar. Ecol. Prog. Ser. 381: 1-15.

Storelli M.M., Barone G., Giacominelli-Stuffler R., Marcotrigiano G.O. 2008 - Levels and profiles of DDTs and PCBs in a gadiform fish (Phycis blennoides) from Mediterranean Sea - Mar. Pollut. Bull. 56: 1367-1370.

Tyler A.V., Dunn R.S. 1976 - Ration, Growth, and Measures of Somatic and Organ Condition in Relation to Meal Frequency in Winter Flounder, Pseudopleuronectes americanus, with Hypotheses Regarding Population Homeostasis - J. Fish. Res. Bd Can. 33: 63-75.

Valero A., Paniagua M.I., Hierro I., Díaz V., Valderrama M.J., Benítez R., Adroher F.J. 2006 - Anisakid parasites of two forkbeards (Phycis blennoides and Phycis phycis) from the Mediterranean coasts of Andalucía (Southern Spain) - Parasitol. Int. 55: 1-5.

Vieira A.R., Sequeira V., Neves A., Paiva R.B., Gordo L.S. 2016 - Reproductive strategy of forkbeard, Phycis phycis, from the Portuguese coast - Helgol. Mar. Res. 70: 3.

Ward-Campbell B.M.S., Beamish F.W.H., Kongchaiya C. 2005 - Morphological characteristics in relation to diet in five coexisting Thai fish species - J. Fish Biol. 67: 1266-1279.

Wilson J.M., Castro L.F.C. 2011 - Morphological diversity of the gastrointestinal tract in fishes - In: The multifonctional gut of fish (Ed.) M. Grosell, Elsevier Inc., Burlington: 1-55. 